\title{
MATURATION OF SPERMATOZOA IN THE RABBIT EPIDIDYMIS: DELAYED FERTILIZATION IN DOES INSEMINATED WITH EPIDIDYMAL SPERMATOZOA
}

\author{
M. C. ORGEBIN-CRIST \\ Department of Obstetrics and Gynecology, Vanderbilt University School of Medicine, \\ Nashoille, Tennessee 37203, U.S.A.
}

(Received 1st May 1967)

\begin{abstract}
Summary. When does are inseminated with spermatozoa from the lower corpus epididymidis, fertilization is strikingly delayed. Sixteen hours after the injection of HCG, fertilization is still in progress. Only $52 \%$ of the ova that will ultimately be fertilized have been penetrated, and in about half of these the fertilizing spermatozoon is just penetrating whereas in control ova fertilized with ejaculated spermatozoa pronuclei are already formed. Ten per cent of ova fertilized with epididymal spermatozoa are polyploid. This abnormal feature is attributed to the fertilization of ageing ova, known to lead to polyploidy in the rabbit. Epididymal spermatozoa are impaired either in their progression in sufficient number into the oviduct and/or in establishing contact with the ovum surface.
\end{abstract}

\section{INTRODUCTION}

It has been reported that, in the rabbit, embryonic mortality is much higher when does are inseminated with immature epididymal spermatozoa than with ejaculated spermatozoa. Losses occur during the pre-implantation period and seem to be related to a delay in ovum development (Orgebin-Crist, 1967). The present paper describes the early events of fertilization when immature epididymal spermatozoa are used for insemination and attempts to elucidate the cause of this delay in ovum development.

\section{MATERIALS AND METHODS}

Fifteen New Zealand White sexually mature, virgin does were used in this study. Each doe was caged individually for 21 days before being used in an experiment. Five males, 9 to 12 months old, were killed to provide epididymal spermatozoa. Three males, 12 to 14 months old, of proven fertility, were used for semen collection. The technique used for preparation of sperm suspensions, for induction of ovulation by human chorionic gonadotrophin (HCG), and for intrauterine insemination have been described elsewhere (Orgebin-Crist, 1967).

Each experiment consisted of a set of three does inseminated with like numbers of spermatozoa $\left(5.5 \pm 0.5 \times 10^{6}\right)$ from the lower corpus, the distal cauda epididymidis, and the ejaculate. It has been our experience that, after uterine 
insemination, reflux from one horn to the other occurs. Consequently, instead of creating an unphysiological situation by ligating the uterine horns which could impair the mechanism of sperm ascent, control insemination of ejaculated spermatozoa was performed in a different doe. Does were killed $16 \mathrm{hr}$ after HCG injection. The oviducts were removed, coiled into a tight flat spiral and fixed in Bouin's fluid. They were then serially sectioned at $7 \mu$ and all the sections were mounted and stained with Harris haematoxylin. All sections were scanned for ova. This method of ovum examination also provided information on the presence of spermatozoa in the lumen of the oviduct and around the ova as well as an accurate assessment of the very early stages of fertilization. The criterion for fertilization was the presence of the fertilizing spermatozoon in the vitellus or the presence of both pronuclei. The classification used to describe the formation of the pronuclei follows the one proposed by Thibault (1967); Stage $1=$ Contact of the fertilizing spermatozoon with the vitellus and rotation of the second maturation spindle. Stage $2=$ Swelling of the fertilizing spermatozoon head in the vitellus and formation of the second polar body. Stage $3=$ Formation of the male and female pronuclei. Stage $4=$ Enlargement and migration of both pronuclei towards the centre of the vitellus. Stage $5=$ Juxtaposition of both pronuclei.

Three sections per oviduct were scanned to ascertain the presence or absence of free spermatozoa in the lumen at the utero-tubal junction, and in the lower and upper half of the oviduct. To determine the number of spermatozoa per ovum, spermatozoa were counted on each serial section of each ovum and these numbers summed to obtain a total figure per ovum.

TABLE 1

PRONUCLEAR FORMATION OF RABBIT OVA AFTER INTRA-UTERINE INSEMINATION OF EPIDIDYMAL OR EJAGULATED SPERMATOZOA (16 HR AFTER HCG INJECTION)

\begin{tabular}{|c|c|c|c|c|c|}
\hline & \multicolumn{2}{|c|}{$\begin{array}{l}\text { Insemination with epididymal } \\
\text { sperm suspension from: }\end{array}$} & \multirow{2}{*}{$\begin{array}{c}\text { Insemination } \\
\text { with } \\
\text { ejaculated } \\
\text { spermatozoa }\end{array}$} & \multicolumn{2}{|c|}{$\begin{array}{l}\text { Normal mating (data } \\
\text { taken from Thibault, } 1967)\end{array}$} \\
\hline & $\begin{array}{l}\text { Lower corpus } \\
\text { epididymidis }\end{array}$ & $\begin{array}{l}\text { Distal cauda } \\
\text { epididymidis }\end{array}$ & & $\begin{array}{c}15 \text { to } 16 \mathrm{hr} \\
\text { p.c. }\end{array}$ & $\begin{array}{c}16 \text { to } 17 \mathrm{hr} \\
\text { p.c. }\end{array}$ \\
\hline $\begin{array}{l}\text { No. of animals } \\
\text { Total No. of ova } \\
\text { No. of fertilized ova } \\
\% \text { fertilization }\end{array}$ & $\begin{array}{l}5 \\
44 \\
13 \\
29 \cdot 5\end{array}$ & $\begin{array}{l}5 \\
36 \\
32 \\
88 \cdot 8\end{array}$ & $\begin{array}{l}5 \\
29 \\
23 \\
79 \cdot 3\end{array}$ & $\begin{array}{c}? \\
35 \\
35 \\
100 \cdot 0\end{array}$ & $\begin{array}{c}? \\
45 \\
45 \\
100 \cdot 0\end{array}$ \\
\hline $\begin{array}{l}\text { Stage } 1 \text { ova }(\%) \\
\text { Stage } 2 \text { ova }(\%) \\
\text { Stage } 3 \text { ova }(\%) \\
\text { tage } 4 \text { ova }(\%) \\
\text { tage } 5 \text { ova }(\%) \\
\text { 2-cell ova }(\%)\end{array}$ & $\begin{array}{c}46 \cdot 1 \\
7 \cdot 6 \\
23 \cdot 0 \\
7 \cdot 6 \\
15 \cdot 3 \\
0\end{array}$ & $\begin{array}{c}0 \\
0 \\
12 \cdot 5 \\
37 \cdot 5 \\
50 \cdot 0 \\
0\end{array}$ & $\begin{array}{l}0 \\
8 \cdot 6 \\
0 \\
34 \cdot 7 \\
56 \cdot 5 \\
0\end{array}$ & $\begin{array}{r}0 \\
6 \\
31 \\
54 \\
9 \\
0\end{array}$ & $\begin{array}{r}0 \\
0 \\
2 \\
62 \\
36 \\
0\end{array}$ \\
\hline
\end{tabular}

\section{RESULTS}

Sixteen hr after injection of HCG only $29.5 \%$ of the ova exposed to spermatozoa from the lower corpus epididymidis were fertilized. Fertilized ova were randomly distributed among the females. Fertilization percentages for ova fertilized with distal cauda or ejaculated spermatozoa were respectively $88 \cdot 8$ and $79 \cdot 3$. 
PLATE 1

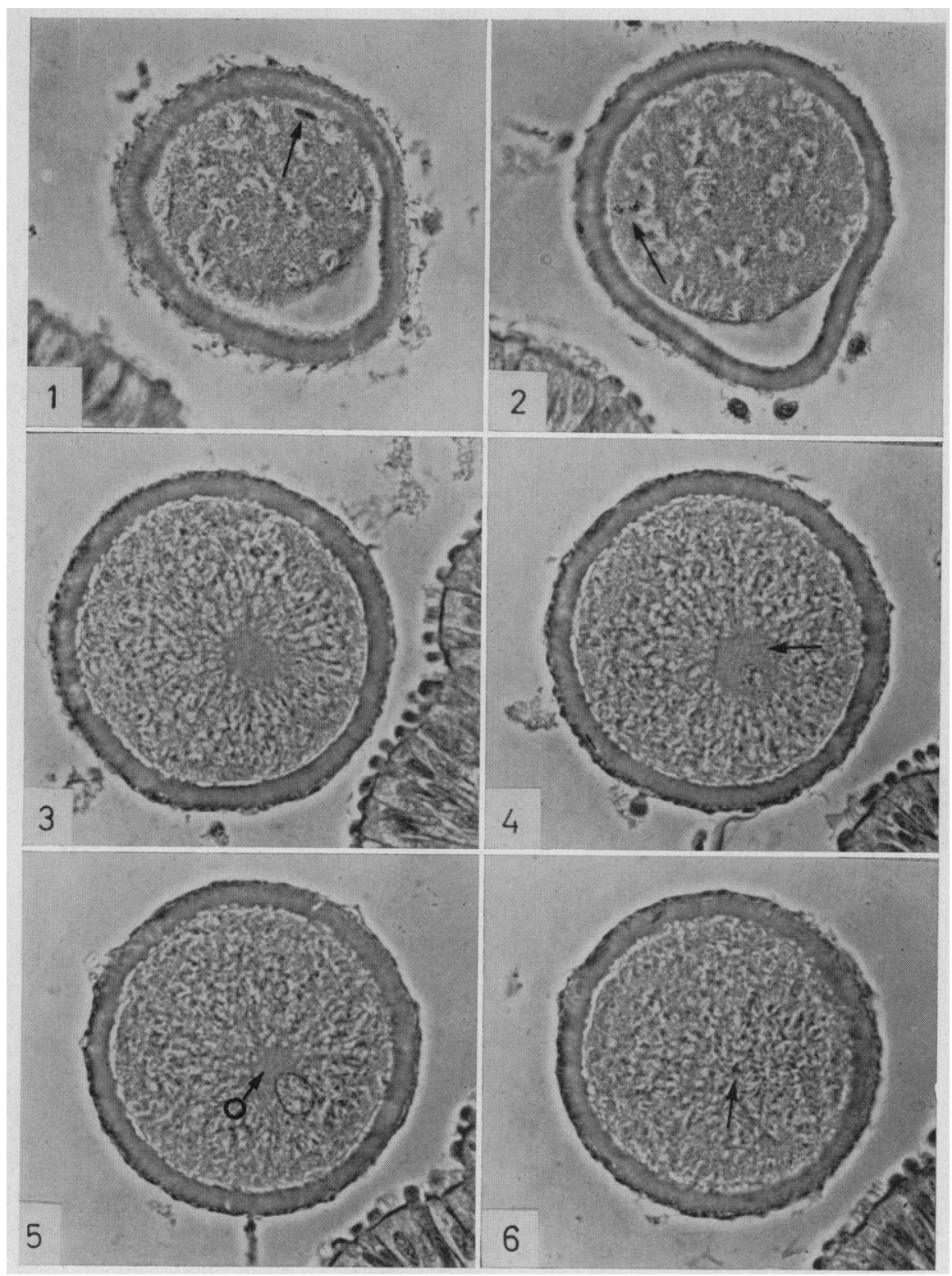

Ficis. 1 to 6 . Rabbit ova fixed, stained, serially sectioned. Phase contrast, $\times 320$.

Figs. 1 and 2. Stage 2 ovum. Notice the fertilizing spermatozoon and the anaphase of the second maturation division (arrows). Figs. 3 to 6. Stage 3 ovum. Notice the pearshaped male pronucleus with the sperm aster (arrow, Figs. 4 and 5) and the chromatin of the female pronucleus (arrow, lig. 6). 
PLATE ?

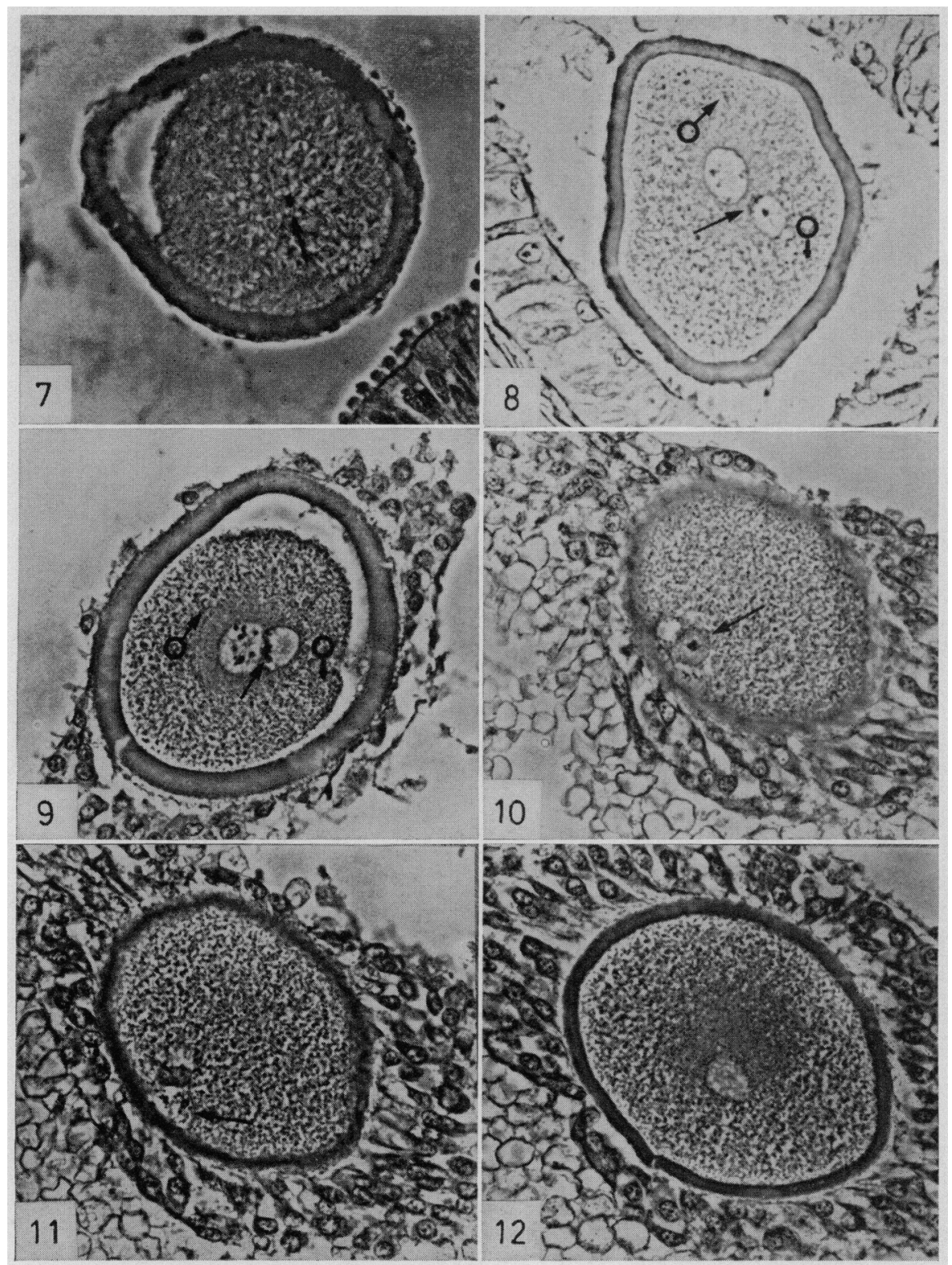

Figs. 7 to 12 . Rabbit ova fixed, stained, serially sectioned. Phase contrast, $\times 320$.

Fig. 7. Continuation of stage 3 ovum. Arrow indicates the female chromatin. Fig. 8. Stage 4 ovum. Fig. 9. Stage 5 ovum. Notice the accumulation of chromatin in the female pronucleus (arrow). Figs. 10 to 13. Dispermic ovum fertilized by spermatozoa from the lower corpus epididymidis. Figs. 10 and 11 . First and second polar bodies (arrows). 


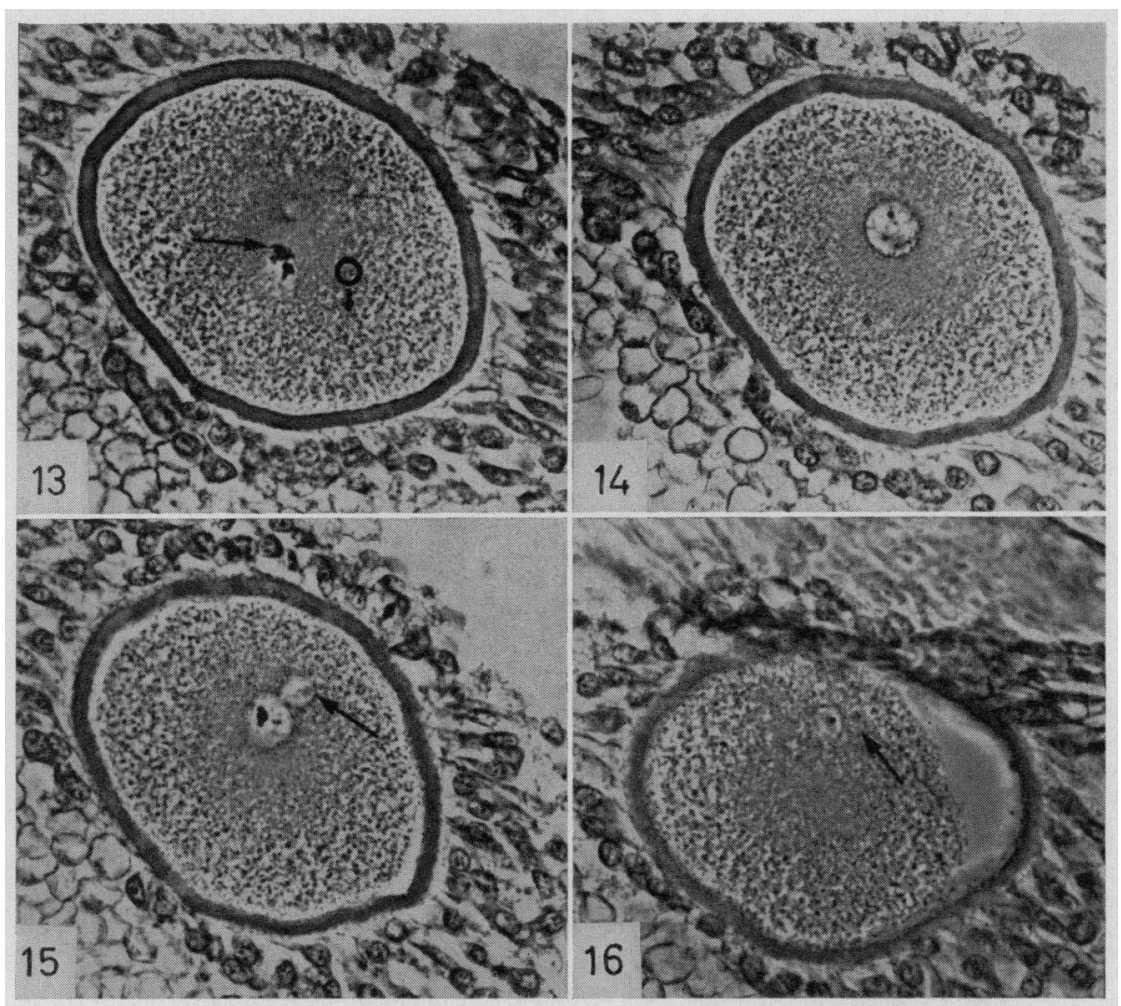

Fiss. 13 to 16. Rabbit ova fixed. stained. serially sectioned. Phase contrast, 320.

ligs. 13 to 16. Continuation of dispermic orum (Plate 2). Fig. 13. Female pronucleus with asymmetric distribution of chromatin. Fig. 14. Male pronucleus. Figs. 15 and 16. second male promucleus arrow. 
PLATE 4

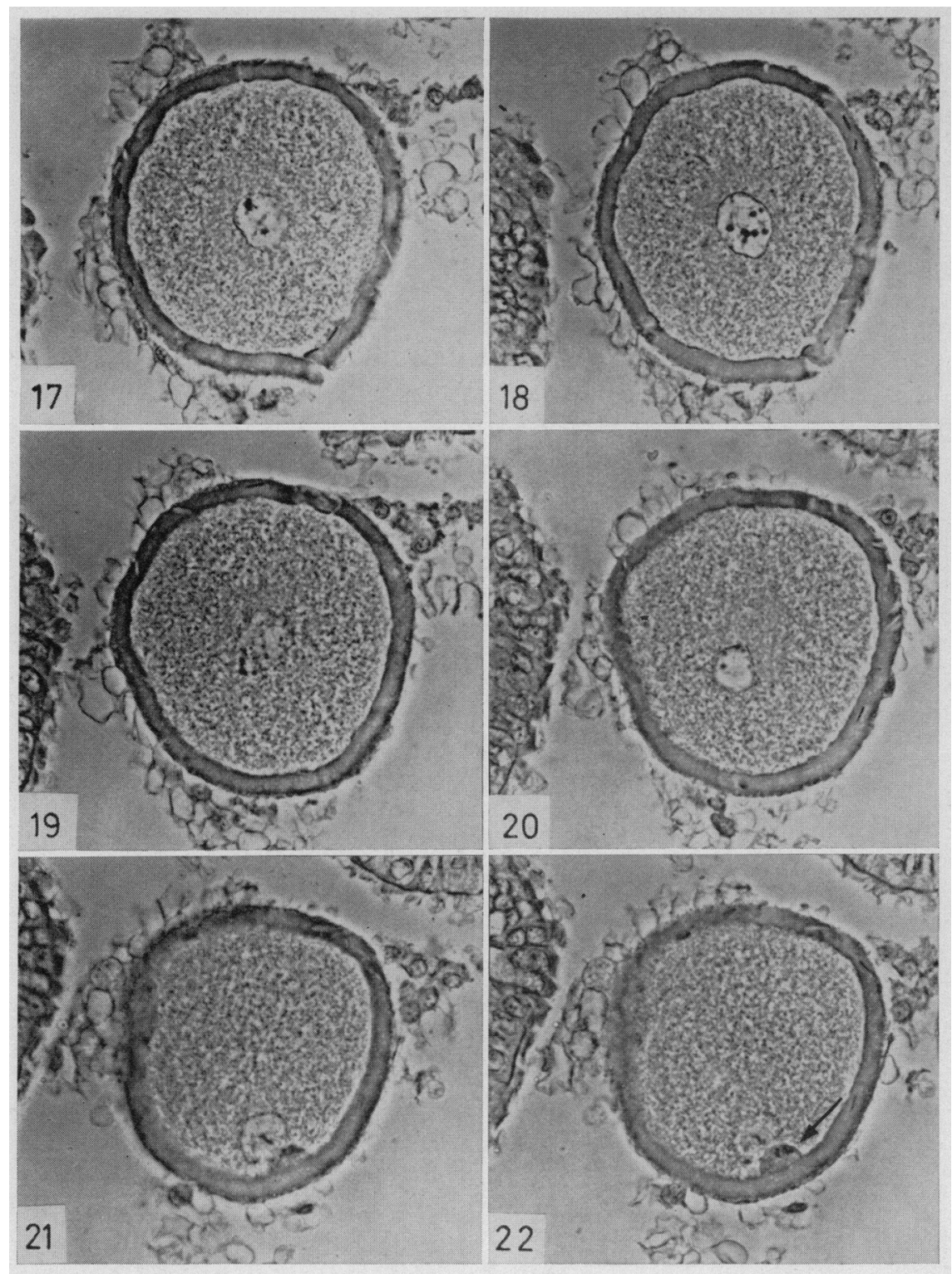

Ficis. 17 to 22. Rabbit ova fixed, stained, serially sectioned. Phase contrast, $\times 320$.

Figs. 17 to 22. Digynic ovum fertilized by spermatozoa from the distal cauda epididymidis. Fig. 21. Third pronucleus. Fig. 22. Single polar body (arrow). 
From Table 1 it can be seen that in $54 \%$ of the ova fertilized by spermatozoa from the lower corpus epididymidis the fertilizing spermatozoon had just penetrated (Stages 1 and 2; Pl. 1, Figs. 1 and 2). In $23 \%$ pronuclei had just been formed (Stage 3; Pl. 1 and 2, Figs. 3 to 7). Percentages were reversed when ova were fertilized with ejaculated spermatozoa: $8.6 \%$ of the ova were in Stages 1 and 2, and $91 \%$ in Stages 4 and 5 (Pl. 2, Figs. 8 and 9).

One ovum out of the six pronuclear ova $(16.6 \%)$ in the lower corpus group had three pronuclei (two normal size, one small and two polar bodies) (Pl. 2 $\& 3$, Figs. 10 to 16). The pronuclei were situated in the centre of the vitellus. One of the two larger ones was identified as the female pronucleus by its asymmetric distribution of chromatin (Oprescu \& Thibault, 1965). Although no sperm tails were distinguishable in the ooplasm, given the presence of two polar bodies, it seems safe to assume that the two remaining pronuclei were male. In this case, the triploidy was attributed to a dispermic fertilization.

TABLE 2

SPERM ASCENT INTO THE OVIDUGT AFTER INTRA-UTERINE INSEMINATION OF EPIDIDYMAL OR EJACULATED SPERMATOZOA (RECOVERY $=16$ HR AFTER HCG INJECTION)

\begin{tabular}{|c|c|c|c|c|}
\hline \multirow[b]{2}{*}{ Source of spermatozoa } & \multirow{2}{*}{$\begin{array}{l}\text { Total No. of } \\
\text { spermatozoal } \\
\text { fertilized } \\
\quad \text { ovum }\end{array}$} & \multicolumn{3}{|c|}{$\%$ oviducts with free spermatozoa in the lumen } \\
\hline & & $\begin{array}{l}\text { Utero-tubal } \\
\text { junction }\end{array}$ & $\begin{array}{l}\text { Lower half of } \\
\text { the oviduct }\end{array}$ & $\begin{array}{l}\text { Upper half of } \\
\text { the oviduct }\end{array}$ \\
\hline $\begin{array}{l}\text { Lower corpus epididymidis } \\
5.5 \pm 0.5 / \text { inseminate }\end{array}$ & $2 \cdot 6 \pm 0 \cdot 1$ & $62 \cdot 5(5 / 8)$ & $0 \quad(0 / 8)$ & $\begin{array}{ll}0 & (0 / 8)\end{array}$ \\
\hline $\begin{array}{l}\text { Distal cauda epididymidis } \\
5.5 \pm 0.5 / \text { inseminate } \\
\text { Ejaculate } 5.5 \pm 0.5 \text { /inseminate }\end{array}$ & $\begin{array}{l}28 \cdot 6 \pm 2 \cdot 2 \\
55 \cdot 1+3 \cdot 1\end{array}$ & $\begin{array}{r}62.5(5 / 8) \\
100.0(8 / 8)\end{array}$ & $\begin{array}{l}25.0(2 / 8) \\
50.0(4 / 8)\end{array}$ & $\begin{array}{l}12.5(1 / 8) \\
12.5(1 / 8)\end{array}$ \\
\hline
\end{tabular}

Three ova out of thirty-two $(9.3 \%)$ in the distal cauda group were triploid. In all of them two pronuclei were present in the centre of the vitellus and the third one at the periphery. These ova had only one polar body and were considered to be digynic by suppression of either the first or second polar body (Pl. 4, Figs. 17 to 22). All ova in the control group were normal.

After insemination with ejaculated or distal cauda spermatozoa, more spermatozoa could be seen either trapped in each fertilized ovum or free in the lumen at the utero-tubal junction or in the oviduct than when lower corpus spermatozoa were inseminated (Table 2).

\section{DISCUSSION}

When ova were recovered 25 to $27 \mathrm{hr}$ after the injection of HCG, $57 \%$ of 142 ova exposed to lower corpus spermatozoa were fertilized (Orgebin-Crist, 1967). In the present series, where recovery took place $16 \mathrm{hr}$ after HCG, only $26 \%$ of the ova were fertilized. Moreover, in half of them, the fertilizing spermatozoon had just penetrated, whereas the pronuclei should have been formed already. This indicates that fertilization, which usually takes place between 10 and $13 \mathrm{hr}$ after the injection of HCG (Pincus, 1939; Thibault, 1967), was still in progress $16 \mathrm{hr}$ after HCG when spermatozoa from the lower corpus epididymidis were 
inseminated. Twenty-five and $27 \mathrm{hr}$ after HCG those ova were still retarded in comparison with the controls (Orgebin-Crist, 1967). Two hypotheses were proposed at that time to explain this abnormal development: either that the cleavage rate was altered or that fertilization was delayed. The data presented here show the second hypothesis to be the correct one.

The cause of this delayed fertilization lies in the inability of the spermatozoa to reach the fertilization site rapidly enough and/or to approach and establish contact with the surface of the ovum. Twenty-four to $28 \mathrm{hr}$ after HCG epididymal spermatozoa were found in great numbers in the oviduct (Orgebin-Crist, 1967). From the present study it can be seen that at the time of fertilization more spermatozoa from the distal cauda or the ejaculate were at the site of fertilization, indicating that although lower corpus spermatozoa do migrate they do so at a slower rate than ejaculated spermatozoa.

Polyploid ova were observed in the present series $(10.5 \%$ of thirty-eight ova). Combining these data with those already reported (Orgebin-Crist, 1967), it was found that $10.2 \%$ of 118 pronuclear ova fertilized with epididymal spermatozoa were polyploid, a figure slightly higher than that reported by Bedford (1966). Respective percentages for the lower corpus, proximal cauda and distal cauda were $11.6(5 / 43), 10.0(1 / 10)$ and $9.2(6 / 65)$. In the rabbit, the incidence of polyploid ova is normally practically zero as can be seen from our combined control series (thirty-four ova) and from the data of Austin \& Braden (1953), Austin (1960), Adams \& Chang (1962) and Thibault (1967). Delayed fertilization, however, leads to spontaneous polyploidy (Austin \& Braden, 1953; Piko, 1958; Thibault, 1959, 1967). Since delayed fertilization was indeed observed after insemination with immature epididymal spermatozoa, it is possible that the appearance of polyploid ova can be attributed to an 'ovum factor' rather than to a 'sperm factor' as such, as suggested by Bedford (1966). The cause of the increased embryonic mortality may then be attributed either to fertilization of aged ova, as suggested by Chang \& Bedford (1962), to the polyploid condition of some of the ova, since in the rabbit polyploid embryos do not seem to be able to survive beyond mid-gestation (Bomsel-Helmreich \& Thibault, 1962), or even to asynchronism, though the difference in question is rather small, between the stages of development of the ova and the uterus, impairing ovum implantation (Chang, 1950).

\section{AGKNOWLEDGMENTS}

I would like to thank Professor C. Thibault, Dr R. Ortavant and Dr M. Courot for the careful criticism of this manuscript and Miss $\mathrm{E}$. Brandon for her expert technical assistance. This research was supported in part by Grant No. HD00673 from the National Institutes of Child Health and Human Development and the Ford Foundation.

\section{REFERENCES}

Adams, C. E. \& Chang, M. C. (1962) Capacitation of rabbit spermatozoa in the Fallopian tube and in the uterus. F. exp. Zool. 151, 159.

Austiv, C. R. (1960) Anomalies of fertilization leading to triploidy. F. cell. comp. Physiol. 56, Suppl. 1, 1 .

Austin, C. R. \& BrADEN, A. W. H. (1953) An investigation of polyspermy in the rat and rabbit. Aust. F. biol. Sci. 6, 674 . 
BEDFord, J. M. (1966) Development of the fertilizing ability of spermatozoa in the epididymis of the rabbit. F. exp. Zool. 163, 319.

Bomsel-Helmreich, O. \& Thibault, C. (1962) Développement d'œufs triploïdes expérimentaux chez la lapine. Annls Biol. anim. Biochim. Biophys. 2, 265.

Chang, M. C. (1950) Development and fate of transferred rabbit ova or blastocysts in relation to the ovulation time of recipients. J. exp. Zool. 114, 197.

Chang, M. C. \& Bedrord, J. M. (1962) Fertilizability of rabbit ova after removal of the corona radiata. Fert. Steril. 13, 421.

ORgebin-Crist, M. C. (1967) Maturation of spermatozoa in the rabbit epididymis: fertilizing ability and embryonic mortality in does inseminated with epididymal spermatozoa. Annls Biol. anim. Biochim. Biophys. 7, 373.

Oprescu, S. \& Thibault, C. (1965) Duplication de l'ADN dans les œufs de lapine après la fécondation. Annls Biol. anim. Biochim. Biophys. 5, 151.

Piko, L. (1958) Etude de la polyspermie chez le rat. C.r. Séanc. Soc. Biol. 152, 1356.

Pincus, G. (1939) The comparative behaviour of mammalian eggs in vivo and in vitro. IV. The development of fertilized and artificially activated eggs. F. exp. Zool. 82, 85.

Thibault, C. (1959) Analyse de la fécondation de l'œuf de la truie après accouplement ou insémination artificielle. Annls Zootech., Suppl., 165.

Thibault, C. (1967) Analyse comparée de la fécondation et de ses anomalies chez la brebis, la vache et la lapine. Annls Biol. anim. Biochim. Biophys. 7, 5. 